\title{
Illusion of control in farmers' investment and financing decisions
}

\author{
Katarina Labajova \\ Independent Researcher, Uppsala, Sweden \\ Julia Höhler \\ Business Economics Group, Wageningen University \& Research, \\ Wageningen, The Netherlands \\ Carl-Johan Lagerkvist \\ Department of Economics, Swedish University of Agricultural Sciences, \\ Uppsala, Sweden \\ Jörg Müller \\ Department of Business Administration of the Agricultural and Food Sector, \\ Justus-Liebig-Universität Giessen, Giessen, Germany, and \\ Jens Rommel \\ Department of Economics, Swedish University of Agricultural Sciences, \\ Uppsala, Sweden
}

\begin{abstract}
Purpose - People's tendency to overestimate their ability to control random events, known as illusion of control, can affect financial decisions under uncertainty. This study developed an artifactual field experiment on illusion of control for a farm machinery investment.

Design/methodology/approach - In an experiment with two treatments, the individual farmer was either given or not given a sense of control over a random outcome. After each decision, the authors elicited perceived control, and a questionnaire collected additional indirect measures of illusion of control from 78 German farmers and 10 farm advisors.

Findings - The results did not support preregistered hypotheses of the presence of illusion of control. This null result was robust over multiple outcomes and model specifications. The findings demonstrate that cognitive biases may be small and difficult to replicate.

Research limitations/implications - The sample is not representative for the German farming population. The authors discuss why the estimated treatment effect may represent a lower bound of the true effect.

Originality/value - Illusion of control is well-studied in laboratory settings, but little is known about the extent to which farmers' behavior is influenced by illusion of control.
\end{abstract}

Keywords Risk and uncertainty, Behavioral finance, Superstition, Framed field experiment, Artifactual field experiment

Paper type Research paper

C Katarina Labajova, Julia Höhler, Carl-Johan Lagerkvist, Jörg Müller and Jens Rommel. Published by Emerald Publishing Limited. This article is published under the Creative Commons Attribution (CC BY 4.0) licence. Anyone may reproduce, distribute, translate and create derivative works of this article (for both commercial and non-commercial purposes), subject to full attribution to the original publication and authors. The full terms of this licence may be seen at http://creativecommons.org/licences/by/4.0/ legalcode

The authors thank the participating farmers for their time and effort. They also thank Helena Hansson and Natalia Montinary for valuable comments on the Swedish pre-study and Rainer Kühl for his support of the German study. We are grateful for research assistance from Leonie Gollisch and excellent comments from the editor Todd Kuethe and two anonymous referees.

Funding: This research did not receive any specific grant from funding agencies in the public, commercial, or not-for-profit sectors.

Received 21 September 2020 Revised 5 July 2021 9 August 2021

Accepted 10 August 2021 
AFR

82,4

676

\section{Introduction}

The objective of this study was to examine illusion of control bias of German farmers related to farm investment and financial decision making. Behavioral economists and cognitive psychologists have long argued that people violate the homo economicus model. People are subject to various cognitive biases (Kahneman, 2011; Kahneman et al., 1982) that also influence their economic and financial decisions (De Bondt and Thaler, 1995; Thaler, 2012; Frydman and Camerer, 2016). People tend to see patterns and meaning in random events (Taleb, 2005). One of the many biases is the so-called illusion of control bias, i.e. people's tendency to overestimate their ability to control random events (Thompson, 1999). Decision makers may believe they have control over random outcomes, such as die rolls or roulette wheels, and such biases can also affect financial decisions under uncertainty (Frydman and Camerer, 2016).

Control over outcomes in different contexts has been discussed for nearly a century (Adler, 1930; Heider, 1958; Kelley, 1967; White, 1959; Presson and Benassi, 1996). In recent decades, researchers have also focused on the factors that mediate illusion of control (Fellner, 2009; Kahai et al., 1998). For instance, Thompson (1999) argues that personal involvement, familiarity, experience and knowledge determine the degree of illusion of control bias. Fenton-O'Creevy et al. (2003) claim that illusion of control is more pronounced in situations that are perceived as stressful or competitive such as financial trading. Charness and Gneezy (2010) show that illusion of control can be alleviated by explicitly asking participants to pay for more control.

Illusion of control is well studied in laboratory settings with students or the general population (Charness and Gneezy, 2010; Ejova et al., 2010; Ginakis and Ohtsuka, 2005; King et al., 2011; Langer, 1975; Ohtsuka and Hyam, 2003; Sloof and von Siemens, 2017; Stephens and Ohtsuka, 2014). Less is known about illusion of control in business and financial decision making (Biais et al., 2005; Fast et al., 2008; Kottemann et al., 1994; Meissner and Wulf, 2017; Simon et al., 2000) and in specific professional contexts (Durand, 2003; Fenton-O'Creevy et al., 2003). Recent studies also highlight the need within policymaking to employ behavioral experiments with farmers (Colen et al., 2016; Dessart et al., 2019; Viceisza, 2016), who face great risks, such as weather and price fluctuations, plant and animal disease, and changing policy environments (Harwood et al., 1999). In addition, there is a need to systematically replicate experiments to arrive at realistic effect size estimates in the literature and to provide a basis for meta-analysis (Camerer et al., 2016; Christensen et al., 2019).

To examine illusion of control bias of German farmers, we applied and compared a measure of illusion of control from a preregistered artifactual field experiment (Harrison and List, 2004) with ex-post stated perceived control over outcomes. We also used psychological scales to assess the magnitude of superstition and illusion of control. Previous research on farmers' financial decision making has largely focused on the elicitation of risk and ambiguity attitudes (e.g. Bocquého et al., 2014; Bougherara et al., 2017; Cerroni, 2020; Herberich and List, 2012; Iyer et al., 2020; Menapace et al., 2016; Vollmer et al., 2017). We add to this emerging literature on farmers' behavior under risk and uncertainty by investigating how cognitive biases are a potential driver of farmers' financial decision making.

The remainder of this paper is organized as follows. In Section 2, we briefly review the theoretical and empirical literature on illusion of control bias and its measurement. Section 3 introduces our study design of an artifactual field experiment on farmers' loan allocation and the complementary measures. Section 4 describes the socio-economic background and farm characteristics of participants. In Section 5, we present and discuss the results of illusion of control bias, as well as some conclusions and areas for future research.

\section{Illusion of control - definitions and measurement}

Langer (1975, p. 113) first coined the term illusion of control, which she defined as "an expectancy of a personal success probability inappropriately higher than the objective 
probability would warrant." Cognitive psychologists have defined illusion of control as a cognitive bias that belongs to the group of positive illusions (Kahneman et al., 1982). Presson and Benassi (1996) note that much of the early work in the field used broad definitions that would be better covered by the term illusion of judgment. They also point out that much of the early empirical work on illusion of control was concerned with the illusion of predictions rather than outcomes. In this study, we applied the rather narrow definition by Thompson (1999), who describes illusion of control as an overestimation of a person's ability to control random events for which the probability distribution is known, e.g. the roll of a die. No matter who rolls the die, where and how, the probability distribution of outcomes is unaffected. If a person believes they have influence over the outcomes of a die roll by rolling the die themselves, it is fair to say that this person is susceptible to illusion of control bias (Charness and Gneezy, 2010; Fellner, 2009; Langer, 1975).

Experiments and surveys are distinct methods to measure illusion of control. In a typical experiment, subjects would be asked to perform different tasks, such as placing a bet or making a hypothetical investment decision, under different treatments which manipulate the subjects' perception of randomness (Charness and Gneezy, 2010; Fellner, 2009; Grou and Tabak, 2008). Survey measures either directly ask respondents about their perceived control over a certain event or use more sophisticated psychological scales to elicit a more general measure of illusion of control (Moodie, 2008; Ohtsuka and Hyam, 2003; Stephens and Ohtsuka, 2014; Wood and Clapham, 2005). Experimental and survey methods are also often combined (Biais et al., 2005; Cowley et al., 2015; Ejova et al., 2010, 2015; Fenton-O'Creevy et al., 2003; Kwak et al., 2010; Meissner and Wulf, 2017; Simon et al., 2000; Yarritu et al., 2014).

\section{Study design, data collection and summary statistics}

Most of the experimental literature on illusion of control has been produced in psychology, but there are also studies in economics and finance. Experiments in economics use incentives contingent on performance and abstain from deception (Hertwig and Ortmann, 2001). Our experiment was based on a simple paper and pen task during a workshop with farmers. Farmers had to make a choice under risk involving salient monetary incentives. We elicited participants' perceived control in the situation shortly before the die roll. Participants also responded to psychometric tests on superstition and illusion of control, parts of which were adapted to fit the context of decision making in agriculture. A survey asked for demographic and financial information, as well as farm characteristics. Finally, subjects received cash payments.

\subsection{Experimental design to measure illusion of control}

Our experimental design was inspired by Fellner (2009), but we adapted it to the context of a German farm manager. An explorative study with Swedish farmers (Labajova, 2018) and exploratory interviews with German farmers guided the experimental design, specifically with respect to framing the decision in a familiar context to enhance external validity and comprehension (cf. Meraner et al., 2018; Rommel et al., 2017, 2019). In an artifactual field experiment, non-student subjects are recruited for participation in an experiment which may help to identify differences in behavior across subject pools and the sensitivity of behavior to context (Cason and Wu, 2019; Rahwan et al., 2019). In a framed field experiment, context is added to the task, because it "is not the case that abstract, context-free experiments provide more general findings if the context itself is relevant to the performance of subjects" (Harrison and List, 2004, p. 1,028). Although we added farming context to the task, the task remained fairly abstract and did not involve unusual rewards. Hence, one may define our experiment as an artifactual field experiment in the typology of Harrison and List (2004), although the experiment also carries some characteristics of a framed field experiment. 
AFR 82,4

\section{8}

Table 1.

Overview on possible outcomes for six possible loan allocations as shown to participants
Our experiment differs from the study of Fellner (2009) in at least one important aspect. We have used a simplified design and refrained from using multiple price lists to ensure that farmers are risk-averse. Note that the decision that farmers were confronted with in the task should in theory be relevant only for risk-averse decision makers (a higher expected value goes along with higher risks). Rather than using multiple price lists, we have learned about farmers' risk attitudes from the scale developed by Dohmen et al. (2011). Although this scale cannot provide a classification based on economic theory, it can provide some hints on risk profiles which we discuss in the results and conclusions sections below.

In the experimental task, participating farmers had to decide on a hypothetical financing decision that involved a loan of 100,000 Euro for the purchase of a new tractor with a repayment period of five years (see supplementary material for all instructions used in the study). The task was not only developed from a pre-study (Labajova, 2018) but also involved informal qualitative interviews with two German farmers. The scenario is realistic in that it uses familiar amounts for the investment and interest rates, although a number of simplifying assumptions were made. The task of the farmer was to allocate the 100,000 Euro between a risky stochastic and a safe deterministic option (see Table 1 for examples of the associated payoffs). The riskier option yielded a higher expected cost saving than the safe option. The decision was incentivized, and 100 Euro of cost saving in the task was associated with a monetary gain of one Euro. The interest rate in the risky option was determined by a die roll (Table 1). Cash payments were implemented double-blind and were calculated based on a simplified formula in Excel [loan cost $=(100,000-$ amount placed in risky option) $\times 2.5 \%+$ amount placed in risky option $\times$ randomly determined interest rate]. Note that this calculation was highly stylized for the purpose of clear communication. The calculation was common knowledge and demonstrated using examples and a table that allowed for linear interpolation (see Table 1 for examples and supplementary material for a

\begin{tabular}{|c|c|c|c|c|c|c|c|}
\hline & \multicolumn{7}{|c|}{ Distribution between fixed and flexible interest rate } \\
\hline & Fixed $(2.5 \%)$ & 100,000 & 80,000 & 60,000 & 40,000 & 20,000 & 0 \\
\hline & Flexible & 0 & 20,000 & 40,000 & 60,000 & 80,000 & 100,000 \\
\hline Outcome of die roll & $\begin{array}{c}\text { Flexible } \\
\text { interest rate }\end{array}$ & \multicolumn{6}{|c|}{ Cost saving contingent on distribution and interest rate outcome } \\
\hline$\cdot$ & $1.90 \%$ & 2,500 & 2,860 & 3,220 & 3,580 & 3,940 & 4,300 \\
\hline \begin{tabular}{|l|}
$\bullet$ \\
\end{tabular} & $2.10 \%$ & 2,500 & 2,740 & 2,980 & 3,220 & 3,460 & 3,700 \\
\hline$\because$ & $2.30 \%$ & 2,500 & 2,620 & 2,740 & 2,860 & 2,980 & 3,100 \\
\hline$\because$ & $2.50 \%$ & 2,500 & 2,500 & 2,500 & 2,500 & 2,500 & 2,500 \\
\hline$\because$ & $2.70 \%$ & 2,500 & 2,380 & 2,260 & 2,140 & 2,020 & 1,900 \\
\hline : : & $2.90 \%$ & 2,500 & 2,260 & 2,020 & 1,780 & 1,540 & 1,300 \\
\hline
\end{tabular}


calculator tool). Payments were always rounded up to the next full Euro amount. The lowest and highest possible payments were 13 and 43 Euro, respectively.

Our experiment had two treatments, implemented between subjects. The experimental treatments differed with respect to the person who rolled the die. In one treatment, participants rolled the die themselves; in the other treatment, the researcher rolled the die. The treatments were balanced within each of the two days of data collection. In other words, approximately half of all participants received one of the two treatments on each of the two days. This practice ensured that differences in the oral instructions, the day of data collection or the composition of the participant group were not confounded with the treatment. The die roll was mentioned only in general terms in the oral instructions: it was never mentioned orally who would roll the die. To minimize the influence of experimenter bias and to avoid demand effects (Zizzo, 2010), this information was only part of the written instructions which were placed in envelopes and randomly distributed to the seats. The written instructions explicitly mentioned who would roll the die. To increase the salience of the die roll treatments, participants had to tick a box on the decision sheet (see supplementary material), stating explicitly that they understood who would roll the die (which is the only information that differed between treatments). After participants had ticked the box, they were asked to decide on their fictitious loan allocation. Anonymity was ensured for all decisions, and small booths were used to ensure privacy (see supplementary material for pictures of the setup). After the decision was made, participants were asked to go to another room to meet a researcher to determine the interest rate by means of the die roll (implemented as indicated in the treatment on the respective sheet).

\subsection{Hypotheses, outcome variables, preregistration and sample size}

If there was no illusion of control bias, it should not have mattered for farmers' decisions who rolled the die. Under the assumption of illusion of control, our main hypothesis was that farmers took greater risks and felt more in control if they rolled the die. We compared three different outcome variables by treatments. First, we were interested in how much farmers allocated to the risky option. Second, we were interested in the proportions of the extremes, i.e. the share of participants that allocated the full 100,000 Euro to either the risky or the safe option. Third, we elicited participants' perceived control in the situation shortly before the die roll which was assessed by a commonly applied single-item rating (Ejova et al., 2010). Participants were asked whether they feel in no to full control over the die roll outcome on a nine-point scale. In principle, perceived control should be zero over purely random outcomes. Thus, any positive value would indicate illusion of control. We also elicited participants' beliefs on the die outcome. They could choose any number or state that all numbers are equally likely (the correct answer).

We preregistered all hypotheses and outcomes before the start of the data collection, and we report all preregistered analyses below (see time-stamped preregistration document in supplementary material). Our sample size calculations were guided by practical limitations, as it is often difficult to recruit a very large number of farmers (Weigel et al., 2021). An expedite ex ante power calculation for the loan allocation outcome and the final design revealed that the study is sufficiently powered to detect large effects (Cohen's $d=0.8$ ) at the usual level of power $p=0.8$ and alpha $=5 \%$ (see time-stamped preregistration document) for a one-sided $t$-test. In the absence of suitable priors for the power calculations, we assumed two scenarios. The optimistic scenario powers for a difference of 20,000 Euro and a standard deviation of 20,000. For a one-sided $t$-test, 13 observations per treatment are needed. The pessimistic scenario assumes a difference of only 15,000 Euro and a higher standard deviation of 25,000 Euro, resulting in a minimum sample size of 35 participants.

Note that the standard deviation in the main outcome of the sample was very close to the 25,000 scenario. 

AFR
82,4

680

\subsection{Recruitment and data collection}

Participants were recruited for a workshop on financial decision making in agriculture in the German federal state of Hesse. The workshop lasted half a day and was free of charge. Information on the workshop was spread through social networks and advisory services. Catering and drinks were offered in addition to the lectures and training sessions. The invitations did not mention the experiment. More than 80 people registered for the workshop (almost everyone who registered also participated) which took place in the premises of the Justus-Liebig-Universität in the German city of Gießen. Participation was split between two consecutive days (February 1 and 2, 2019). The experiment was embedded in the broader context of the workshop. After all decisions were made, the aggregated data were presented to participants, and a short debriefing and discussion took place. Participants received oral instructions supported by a power point presentation (see supplementary material). A strict script was applied to ensure consistency across both days of the workshop. The oral instructions used various calculation examples to enhance comprehension, but we carefully selected diverse examples to avoid priming (see supplementary material). In addition, there were written instructions (see supplementary material). Participants were allowed to ask questions in private.

\subsection{Additional survey instruments to elicit illusion of control}

There are different psychological scales within psychology to study illusion of control. For instance, Kwak et al. (2010) and Moore and Ohtsuka (1999) have developed scales with a limited number of items to evaluate illusion of control in the context of gambling. Here, we opted for the more elaborate Drake Beliefs about Chance (DBC) inventory, which was also originally developed in the context of gambling but includes more items (Wood and Clapham, 2005). The original scale consists of 22 items and explicitly distinguishes superstition and illusion of control dimensions. Some of the items were developed in the context of gambling and did not suit our context very well. We carefully evaluated the items and used a shortened list of 18 items, 14 from the original scale and 4 adapted to an agricultural context (see supplementary material and Table 5 below). One item was reversed, and we recoded it for the analysis.

\subsection{Summary statistics}

Table 2 displays summary statistics of the participants. Participants were predominately male with an average age of approximately 45 years. The majority of participants were active

\begin{tabular}{|c|c|c|c|c|c|c|}
\hline & Mean & Median & $\begin{array}{l}\text { Standard } \\
\text { deviation }\end{array}$ & $N$ & Minimum & Maximum \\
\hline Gender (1 = female) & 0.06 & & & 88 & 0 & 1 \\
\hline Age (years) & 44.83 & 47 & 14.93 & 88 & 18 & 74 \\
\hline Farming $(1=$ active farmer $)$ & 0.89 & & & 88 & 0 & 1 \\
\hline $\begin{array}{l}\text { Main income }(1=\text { agriculture main } \\
\text { income) }\end{array}$ & 0.42 & & & 78 & 0 & 1 \\
\hline Livestock units & 17.57 & 0 & 38.00 & 77 & 0 & 180 \\
\hline Arable land (hectares) & 88.27 & 80 & 75.91 & 77 & 1.50 & 438 \\
\hline $\begin{array}{l}\text { Economics courses ( }=1 \text { has training in } \\
\text { economics) }\end{array}$ & 0.72 & & & 78 & 0 & 1 \\
\hline $\begin{array}{l}\text { Risk attitude (11-point scale following } \\
\text { Dohmen } \text { et al., 2011) }\end{array}$ & 5.43 & 6 & 1.80 & 88 & 2 & 8 \\
\hline
\end{tabular}

Table 2.

Summary statistics 
farmers; the ten other participants were farm advisors whom we include for the main analysis. Note that we have run all major analysis also with the subsample of farmers and did not find major differences. For approximately $42 \%$ of the farming participants, farming was their main income. Farms were quite diverse in terms of livestock units and cultivated area with a range of 0-180 livestock units and 1.5-438 hectares, respectively. A majority of the farming participants had received at least some economic training. We also elicited risk attitudes, using the simple 11-point scale question from Dohmen et al. (2011). The distribution is similar to the Dohmen et al. study, but the modal respondent is somewhat more willing to take risks in our sample (modal respondent chose 8 in our sample but 5 in the Dohmen study).

The average, median, minimum and maximum cash payment farmers received were 26.69, 25, 15.40 and 43 Euro, respectively. The standard deviation was 6.23 Euro.

\subsection{How representative are the sampled farms for the German farming population?}

Farmers are difficult to recruit for the participation in experiments which increases the risks of biased samples (Weigel et al., 2021). To become aware of potential biases, it is useful to compare the sample to the population of all German farms as well as farms in the federal state of Hesse. According to the Federal Ministry of Food and Agriculture (2018, p. 24), conventional farms in Germany utilized approximately 91.9 hectares on average in 2017/18 (86.7 hectares for organic farms). Conventional farms made an average profit of 39,107 Euro (40,641 Euro for organic farms). While conventional farms had on average 145.3 livestock units per 100 hectare, with 82.7 livestock units per 100 hectare this figure was much lower for organic farms. The farms in our sample have a similar size but fewer livestock units than the average German farm. However, it must be noted that farms in the federal state of Hesse are typically smaller than in other parts of Germany (see Statistik Hessen, 2011 for the latest detailed available figures from 2010). In 2020, there were approximately 15,130 farms in the state of Hesse, farming a total of 764,700 ha. Hence, the average farm size was approximately 50.5 hectares (Destatis, 2021), indicating a bias toward large farms in our sample. There were only few women in our sample. Population statistics on the farmers with vocational training show that approximately 17 percent were women in 2016 (German Farmers' Association, 2021).

It is also useful to compare the risk attitudes of our sample to population data. Dohmen et al. (2011) found an average score of $4.42(\mathrm{SD}=2.38)$ which was substantially higher for men (mean $=4.91$ ). In a sample of German farmers, Maart-Noelck and Musshoff (2014) find that farmers are slightly more risk-seeking than the Dohmen sample which is similar to our sample, displaying a value of 5.43 (which is also highly skewed toward male participants). In conclusion, our sample cannot be considered representative for the German farming population or farms in the federal state of Hesse for the mentioned characteristics. However, under the assumption of homogeneous treatments effects, i.e. treatment effects do not interact with characteristics of participants, we can still obtain an unbiased estimate of the treatment effect.

\section{Results}

\subsection{Illusion of control measures by treatments}

Our main outcome variable of interest was the loan amount allocated to the risky option. We compared this variable between subjects by treatments. Results are displayed in Table 3.

Participants allocated about the same amounts to the risky and safe options across all possible outcomes and tests. In most instances, and in contrast to our hypothesis, participants allocated less to the risky option when they were in control of the die roll. Yet, none of the differences are statistically significant. 
AFR
82,4

682

Table 3.

Major outcomes by treatments

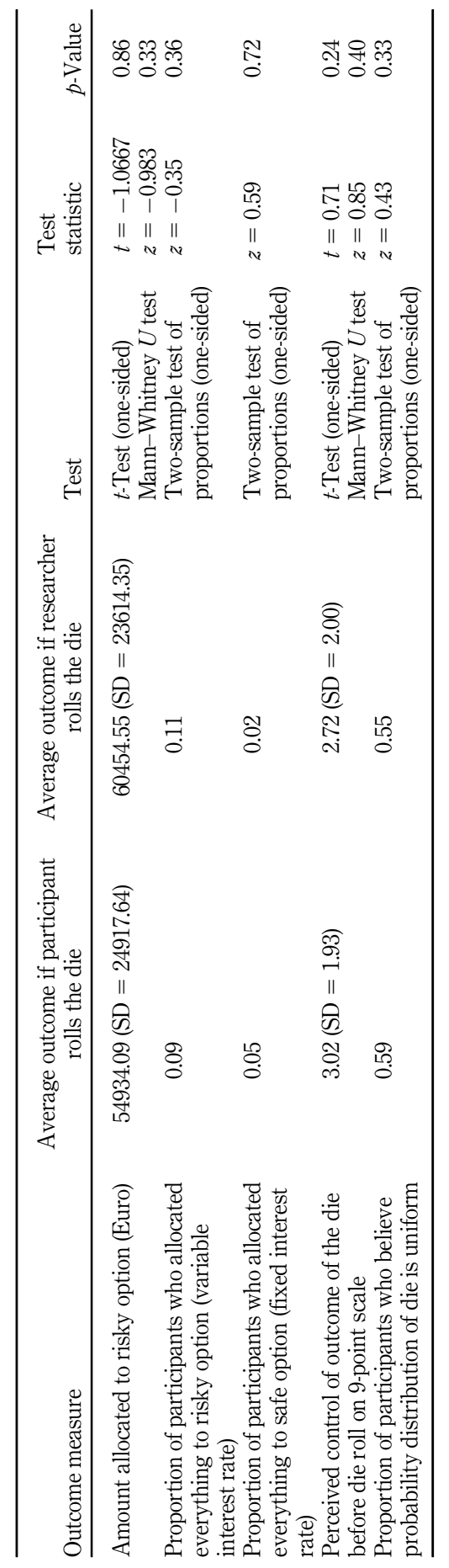




\subsection{Controlling for heterogeneity}

Table 4 displays coefficient estimates of three Ordinary Least Squares (OLS) models with the amount allocated to the risky option as the dependent variable. The model in column (1) only includes the experimental variables, that is, a treatment dummy and the day of data collection (recall that data collection took place on Friday and on Saturday). Column (2) also includes gender, age and risk attitude. Column (3) only reports outcomes for the farmer sample and includes four farm level variables: farming is main income, livestock units, farm area and economic training.

The regressions confirm the analysis from the previous section. Treatment effects are in the opposite of the expected direction, small and statistically insignificant. Note that the gender coefficient is large in absolute terms, with women being substantially more riskaverse. However, the effect is not statistically significant, and there were very few women in the sample. There is a fairly large effect of the risk attitude in the expected direction (riskseeking farmers place more money in the risky option), albeit it is statistically significant at the $5 \%$ level only in the model presented in column (2). A one-point increase in the selfassessed willingness to accept risks leads to a greater willingness to allocate money to the risky option in the experimental task of approximately 2,800 Euro. The 95\% confidence interval was the estimate and is 5.9 to 5758.7 in column (2) and - 157.0 to 6537.4 in column (3).

The estimated models have small explanatory power as indicated by the small $F$-statistics and adjusted $R^{2}$ values. Predicted values for all models are within the defined interval of 0-100,000 Euro, and there are few censored observations $(<15 \%)$. Hence, we decided not to estimate Tobit models.

As noted above, our sample may have been biased towards risk-seeking farmers, whereas the theoretical framework required risk-averse farmers. We have performed additional analysis with an interaction effect of treatment and risk attitude. The estimated coefficient was positive but statistically not significant. We have also repeated the analysis for the subsample that had Dohmen scores of 6 or less ( 30 observations with scores 7 or 8 were removed). The results do not change qualitatively, but the treatment effect estimates increased (albeit the treatment effect was still fairly small and statistically not significant) which could indicate that a more risk-averse sample would indeed show a larger treatment effect, although the

\begin{tabular}{|c|c|c|c|}
\hline & (1) & (2) & (3) \\
\hline Treatment $(1=$ researcher rolls the die $)$ & $5520.5(5165.5)$ & $3831.2(5102.2)$ & $1653.4(5752.7)$ \\
\hline Friday $(1=$ Friday $)$ & $-5956.8(5165.5)$ & $-6433.2(5085.3)$ & $-6204.9(5849.4)$ \\
\hline Gender ( 1 = female $)$ & & $-18845.7(11,147.2)$ & $-6150.8(32,506.6)$ \\
\hline Age (years) & & $-170.3(177.1)$ & $-152.2(215.4)$ \\
\hline Risk attitude (11-point scale following & & $2882.4^{*}(1445.9)$ & $3190.2(1677.0)$ \\
\hline Dohmen et al., 2011) & & & \\
\hline $\begin{array}{l}\text { Main income }(1=\text { agriculture main } \\
\text { income) }\end{array}$ & & & $9158.4(8292.3)$ \\
\hline Livestock units & & & $-46.62(80.33)$ \\
\hline Arable land (hectares) & & & $-25.37(63.54)$ \\
\hline $\begin{array}{l}\text { Economics courses (= } 1 \text { has training in } \\
\text { economics) }\end{array}$ & & & $7011.9(6564.3)$ \\
\hline Constant & $52392.0^{* * * *}(8566.0)$ & $48212.0^{* * *}(12925.5)$ & $43811.7^{* *}(14732.8)$ \\
\hline Observations & 88 & 88 & 77 \\
\hline$F$ & 1.236 & 1.855 & 1.187 \\
\hline Adj. $R^{2}$ & 0.0054 & 0.0469 & 0.0217 \\
\hline
\end{tabular}

Note(s): Standard errors in parentheses * $p<0.05,{ }^{* *} p<0.01,{ }^{* * *} p<0.001$
Illusion of control

683 
AFR
82,4

Summary statistics for items on superstition and illusion of control

Standard

deviation $\quad N$ Minimum Maximum

Superstition (Cronbach's alpha $=0.75$ )

I like to carry a lucky coin, charm or token when I'm doing something important

I can improve my chances of winning by performing special rituals

There may be magic in certain numbers

When I take a test (or took them in the past) I use a lucky pen or pencil

There is useful information in my daily horoscope $\quad 1.70$

When I need a little luck I wear lucky clothes or jewelry

A game of chance is a contest of wills between the game and the player

I believe that fate is against me when I lose

I do not consider myself to be a superstitious person.

(Reverse scored)

Mean

$\begin{array}{lllll}2.17 & 0.99 & 88 & 1 & 4 \\ 2.03 & 1.04 & 88 & 1 & 4 \\ & & & & \\ 2.14 & 0.90 & 88 & 1 & 4 \\ 1.77 & 0.82 & 87 & 1 & 4 \\ & & & & \\ 1.70 & 0.82 & 88 & 1 & 4 \\ 1.85 & 0.95 & 87 & 1 & 5 \\ 2.85 & 1.14 & 88 & 1 & 5 \\ 2.25 & 1.06 & 88 & 1 & 5 \\ 2.29 & 1.24 & 73 & 1 & 5\end{array}$

Illusion of control (Cronbach's alpha $=0.74$ )

It is good advice to stay with the same pair of dice on a 2.46 winning streak

One should pay attention to lottery numbers that often 2.43 win

If a coin is tossed and comes up heads ten times in a row, 2.41

the next toss is more likely to be tails

Some people are just born lucky

The longer I've been losing, the more likely I am to win 2.48

Contextually framed statements (Cronbach's alpha $=0.58$ )

One can learn to pick a good interest rate $\quad 3.44$

The more I know about loans, the earlier I can get a low 3.59

interest rate

I will save money by using a system to predict the $\quad 3.39$

interest rate

If my farm yield was low for several years, the $\quad 2.46$

probability of a high yield increases

$\begin{array}{llll}1.04 & 87 & 1 & 5 \\ 0.98 & 87 & 1 & 4 \\ 1.14 & 87 & 1 & 5 \\ 0.93 & 86 & 1 & 5 \\ 0.96 & 87 & 1 & 4\end{array}$

$\begin{array}{llll}0.87 & 87 & 1 & 5\end{array}$

$\begin{array}{llll}0.91 & 87 & 1 & 5\end{array}$

$\begin{array}{llll}0.94 & 87 & 1 & 5\end{array}$

$\begin{array}{llll}0.96 & 87 & 1 & 4\end{array}$

sample was too small to make such a statement with great confidence. Detailed results are presented in the supplementary material.

\subsection{Drake Beliefs about chance inventory}

Table 5 displays summary statistics for the 18 survey items on superstition and illusion of control. Overall, there are low levels of superstition. The average across all items is not correlated with the amount allocated to the risky option in the experiment (Pearson's $r=-0.05, p=0.67$ ). If we apply a factor analysis, extracting two factors for the superstition and illusion of control items or three factors if we include the contextually framed items, factor loadings indicate a poor fit (in spite of relatively high scale reliability).

\section{Discussion and conclusions}

Farmers face high risks of seasonal production, changing weather conditions, price fluctuations and volatile policy environments. To measure illusion of control in farmers' financial decision making, we conducted an artifactual field experiment in which a sample of 
German farmers had to allocate a loan to a risky and a safe option. Our treatments were manipulations of who rolls a die in the experiment (researcher or farmer) to determine random outcomes with respect to interest rates. We complemented our data with questionnaire measures of perceived control and elicited illusion of control, using a psychological scale. A caveat of our approach was that farmers were not representative of the German or regional farming population for several important characteristics. In addition, our study attracted a greater than expected number of risk-seeking farmers for whom the benchmark theoretical model of a risk-averse decision maker would not necessarily hold.

We did not find treatment effects in the experiment. In our study, there was no evidence of illusion of control. Note that we pre-registered our hypotheses and analyses. Our experiment did have sufficient statistical power (alpha $=0.05$; beta $=0.2$ ) to detect large effects (Cohen's $d=0.8$ ). Our analysis of loan allocations suggested that farmers' decisions were not influenced by illusion of control bias. Note that a similar result was obtained in a small study of Swedish farmers (Labajova, 2018). Although there could still be type II error, one may ask how practically relevant the many small cognitive biases identified in the psychological literature are in the day-to-day decisions of farmers. Our sample may be biased toward educated farmers with high financial literacy, but we did not find an effect of economic education or other covariates on risk-taking in the experiment. Given potential biases in the sample on observed and unobserved characteristics, our treatment effect estimate must be generally interpreted with care. Under the assumption that the treatment effect interacts with education and financial literacy, it should be viewed as a lower bound, i.e. the effect of illusion of control could be higher in the population.

Our experimental measures of illusion showed no significant correlation with the more general psychological scales developed to measure superstition and illusion of control. The experiment and the survey might have measured different latent constructs. More research is needed on how to operationalize and contextualize the measurement of cognitive biases in general and of illusion of control in particular. Existing validated scales could be adapted and extended for this purpose (see Hansson and Lagerkvist, 2012 for a discussion on the use of psychometric scales).

Real-life economic decisions are complex, and we need to develop methods to understand this type of decision making where it happens. Policymakers invest a great deal of effort in taking farmers' financial decisions into account. Our analysis did not find evidence for irrational decision making. However, other research points out that farmers may still not be easily treated as following a homo economicus model of rationality as typically assumed in simulation models for agricultural policy analysis (Dessart et al., 2019; Howley, 2015). Taking into account cognitive biases in farmers' financial decision making for policy analysis remains an important route for future research.

\section{References}

Adler, A. (1930), "Individual psychology", in Murchison, I.C. (Ed.), Psychologies of 1930, Clark University Press, Worcester, MA.

Biais, B., Hilton, D., Mazurier, K. and Pouget, S. (2005), "Judgemental overconfidence, self-monitoring, and trading performance in an experimental financial market", Review of Economic Studies, Vol. 72 No. 2, pp. 287-312.

Bocquého, G., Jacquet, F. and Reynaud, A. (2014), "Expected utility or prospect theory maximisers? Assessing farmers' risk behaviour from field-experiment data", European Review of Agricultural Economics, Vol. 41 No. 1, pp. 135-172.

Bougherara, D., Gassmann, X., Piet, L. and Reynaud, A. (2017), "Structural estimation of farmers' risk and ambiguity preferences: a field experiment", European Review of Agricultural Economics, Vol. 44 No. 5, pp. 782-808.
Illusion of control 
AFR 82,4
Camerer, C.F., Dreber, A., Forsell, E., Ho, T.H., Huber, J., Johannesson, M., Kirchler, M., Almenberg, J., Altmejd, A., Chan, T., Heikensten, E., Holzmeister, F., Imai, T., Isaksson, S., Nave, G., Pfeiffer, T., Razen, M. and Wu, H. (2016), "Evaluating replicability of laboratory experiments in economics", Science, Vol. 351 No. 6280, pp. 1433-1436.

Cason, T.N. and Wu, S.Y. (2019), "Subject pools and deception in agricultural and resource economics experiments", Environmental and Resource Economics, Vol. 73 No. 3, pp. 743-758.

Cerroni, S. (2020), "Eliciting farmers' subjective probabilities, risk and uncertainty preferences using contextualized field experiments", Agricultural Economics, Vol. 51 No. 5, pp. 707-724.

Charness, G. and Gneezy, U. (2010), "Portfolio choice and risk attitudes: an experiment", Economic Inquiry, Vol. 48 No. 1, pp. 133-146.

Christensen, G., Freese, J. and Miguel, E. (2019), Transparent and Reproducible Social Science Research: How to Do Open Science, University of California Press, Berkeley, California.

Colen, L., Gomez y Paloma, S., Latacz-Lohmann, U., Lefebvre, M., Préget, R. and Thoyer, S. (2016), "Economic experiments as a tool for agricultural policy evaluation: insights from the European CAP”, Canadian Journal of Agricultural Economics/Revue Canadienne D'agroeconomie, Vol. 64 No. 4, pp. 667-694.

Cowley, E., Briley, D.A. and Farrell, C. (2015), "How do gamblers maintain an illusion of control?", Journal of Business Research, Vol. 68 No. 10, pp. 2181-2188.

De Bondt, W.F.M. and Thaler, R.H. (1995), "Chapter 13 Financial decision-making in markets and firms: a behavioral perspective", Handbooks in Operations Research and Management Science, Elsevier, pp. 385-410.

Dessart, F.J., Barreiro-Hurlé, J. and van Bavel, R. (2019), "Behavioural factors affecting the adoption of sustainable farming practices: a policy-oriented review", European Review of Agricultural Economics, Vol. 46 No. 3, pp. 417-471.

Destatis (2021), "Betriebsgrößenstruktur landwirtschaftlicher Betriebe nach Bundesländern", available at: https://www.destatis.de/DE/Themen/Branchen-Unternehmen/LandwirtschaftForstwirtschaft-Fischerei/Landwirtschaftliche-Betriebe/Tabellen/betriebsgroessenstrukturlandwirtschaftliche-betriebe.html.

Dohmen, T., Falk, A., Huffman, D., Sunde, U., Schupp, J. and Wagner, G.G. (2011), "Individual risk attitudes: measurement, determinants, and behavioral consequences", Journal of the European Economic Association, Vol. 9 No. 3, pp. 522-550.

Durand, R. (2003), "Predicting a firm's forecasting ability: the roles of organizational illusion of control and organizational attention”, Strategic Management Journal, Vol. 24 No. 9, pp. 821-838.

Ejova, A., Delfabbro, P.H. and Navarro, D.J. (2010), "The illusion of control: structure, measurement and dependence on reinforcement frequency in the context of a laboratory gambling task", in Christensen, W., Schier, E. and Sutton, J. (Eds), Proceedings of ASCS09: Proceedings of the 9th Conference of the Australasian Society for Cognitive Science, Macquarie Centre for Cognitive Science, Sydney, pp. 84-92, available at: http://www.maccs.mq.edu.au/news/conferences/2009/ ASCS2009/html/ejova.html.

Ejova, A., Delfabbro, P.H. and Navarro, D.J. (2015), "Erroneous gambling-related beliefs as illusions of primary and secondary control: a confirmatory factor analysis", Journal of Gambling Studies, Vol. 31 No. 1, pp. 133-160.

Fast, N.J., Gruenfeld, D.H., Sivanathan, N. and Galinsky, A.D. (2008), "Illusory control: a generative force behind power's far-reaching effects", Research Paper Series (2009), available at: http:// ssrn.com/abstract $=1314952$.

Federal Ministry of Food and Agriculture (2018), "Die wirtschaftliche Lage der landwirtschaftlichen Betriebe 2018", available at: https://www.bmel-statistik.de/fileadmin/daten/BFB-01111012018.pdf.

Fellner, G. (2009), "Illusion of control as a source of poor diversification: experimental evidence", Journal of Behavioral Finance, Vol. 10 No. 1, pp. 55-67. 
Fenton-O'Creevy, M., Nicholson, N., Soane, E. and Willman, P. (2003), “Trading on illusions: unrealistic perceptions of control and trading performance", Journal of Occupational and Organizational Psychology, Vol. 76, pp. 53-68.

Frydman, C. and Camerer, C.F. (2016), "The psychology and neuroscience of financial decision making”, Trends in Cognitive Sciences, Vol. 20 No. 9, pp. 661-675.

German Farmers' Association (2021), "DBV-Situationsbericht", available at: https://www. bauernverband.de/situationsbericht/3-agrarstruktur-1/35-arbeitskraefte-und-auszubildende.

Ginakis, S. and Ohtsuka, K. (2005), "Problem gambling: an exploration of the role of global personal hopefulness, short-term gambling hope, and illusion of control beliefs", Gambling Research, Vol. 17 No. 2, pp. 7-16.

Grou, B. and Tabak, B.M. (2008), "Ambiguity aversion and illusion of control: experimental evidence in an emerging market", Journal of Behavioral Finance, Vol. 9 No. 1, pp. 22-29.

Hansson, H. and Lagerkvist, C.J. (2012), "Measuring farmers' preferences for risk: a domain-specific risk preference scale", Journal of Risk Research, Vol. 15 No. 7, pp. 737-753.

Harrison, G.W. and List, J.A. (2004), "Field experiments", Journal of Economic Literature, Vol. 42 No. 4, pp. 1009-1055.

Harwood, J.L., Heifner, R., Coble, K., Perry, J. and Somwaru, A. (1999), Managing Risk in Farming: Concepts, Research, and Analysis, US Department of Agriculture, Economic Research Service, Washington, DC.

Heider, F. (1958), The Psychology of Interpersonal Relations, Wiley, New York.

Herberich, D.H. and List, J.A. (2012), "Digging into background risk: experiments with farmers and students", American Journal of Agricultural Economics, Vol. 94 No. 2, pp. 457-463.

Hertwig, R. and Ortmann, A. (2001), "Experimental practices in economics: a methodological challenge for psychologists?”, Behavioral and Brain Sciences, Vol. 24, pp. 383-451.

Howley, P. (2015), "The happy farmer: the effect of nonpecuniary benefits on behavior", American Journal of Agricultural Economics, Vol. 97 No. 4, pp. 1072-1086.

Iyer, P., Bozzola, M., Hirsch, S., Meraner, M. and Finger, R. (2020), "Measuring farmer risk preferences in Europe: a systematic review", Journal of Agricultural Economics, Vol. 71 No. 1, pp. 3-26.

Kahai, S.S., Solieri, S.A. and Felo, A.J. (1998), "Active involvement, familiarity, framing, and the illusion of control during decision support system use", Decision Support Systems, Vol. 23 No. 2, pp. 133-148.

Kahneman, D. (2011), Thinking, Fast and Slow, Macmillan, London.

Kahneman, D., Slovic, P. and Tversky, A. (1982), Judgment under Uncertainty: Heuristics and Biases, Cambridge University Press, Cambridge.

Kelley, H.H. (1967), "Attribution theory in social psychology”, in Levine, D. (Ed.), Nebraska Symposium on Motivation, University of Nebraska Press, Lincoln, pp. 192-238.

King, D.L., Ejova, A. and Delfabbro, P.H. (2011), "Illusory control, gambling, and video gaming: an investigation of regular gamblers and video game players", Journal of Gambling Studies, Vol. 28, pp. 421-435.

Kottemann, J.E., Davis, F.D. and Remus, W.E. (1994), "Computer-assisted decision making: performance, beliefs, and the illusion of control", Organizational Behavior and Human Decision Processes, Vol. 57, pp. 26-37.

Kwak, D.H., Lim, C.H., Lee, W.Y. and Mahan, J. III (2010), "How confident are you to win your fantasy league: exploring the antecedents and consequences of winning expectancy", Journal of Sport Management, Vol. 24 No. 4, pp. 416-433.

Labajova, K. (2018), "Essays on pig production efficiency and farmers' financial decisions under uncertainty", PhD Dissertation, Swedish University of Agricultural Sciences.

Langer, E.J. (1975), "The illusion of control”, Journal of Personality and Social Psychology, Vol. 32 No. 2, pp. 311-328. 
AFR

82,4

688

Maart-Noelck, S.C. and Musshoff, O. (2014), "Measuring the risk attitude of decision-makers: are there differences between groups of methods and persons?", Australian Journal of Agricultural and Resource Economics, Vol. 58 No. 3, pp. 336-352.

Meissner, P. and Wulf, T. (2017), "The effect of cognitive diversity on the illusion of control bias in strategic decisions: an experimental investigation”, European Management Journal, Vol. 35 No. 4, pp. 430-439.

Menapace, L., Colson, G. and Raffaelli, R. (2016), "A comparison of hypothetical risk attitude elicitation instruments for explaining farmer crop insurance purchases”, European Review of Agricultural Economics, Vol. 43 No. 1, pp. 113-135.

Meraner, M., Musshoff, O. and Finger, R. (2018), "Using involvement to reduce inconsistencies in risk preference elicitation”, Journal of Behavioral and Experimental Economics, Vol. 73, pp. 22-33.

Moodie, C. (2008), "Student gambling, erroneous cognitions, and awareness of treatment in Scotland", Journal of Gambling Issues, Vol. 21, pp. 30-55.

Moore, S.M. and Ohtsuka, K. (1999), "Beliefs about control over gambling among young people, and their relation to problem gambling", Psychology of Addictive Behaviors, Vol. 13 No. 4, pp. 339-347.

Ohtsuka, K. and Hyam, P. (2003), "Internal and external attribution of success and failure in gambling and nongambling situation", in Coman, G., Walker, M., Jackson, A. and Thomas, P. (Eds), Proceedings of The proceedings of the 12th Annual National Association for Gambling Studies Conference, Melbourne, November 2002, The National Association for Gambling Studies, Alphington, Australia, pp. 357-369.

Presson, P.K. and Benassi, V.A. (1996), "Illusion of control: a meta-analytic review", Journal of Social Behavior and Personality, Vol. 11 No. 3, pp. 493-510.

Rahwan, Z., Yoeli, E. and Fasolo, B. (2019), "Heterogeneity in banker culture and its influence on dishonesty”, Nature, Vol. 575 No. 7782, pp. 345-349.

Rommel, J., Hermann, D., Müller, M. and Mußhoff, O. (2017), "Comprehension in risk elicitation experiments", Applied Economics Letters, Vol. 24 No. 9, pp. 627-634.

Rommel, J., Hermann, D., Müller, M. and Mußhoff, O. (2019), "Contextual framing and monetary incentives in field experiments on risk preferences: evidence from German farmers", Journal of Agricultural Economics, Vol. 70 No. 2, pp. 408-425.

Simon, M., Houghton, S. and Aquino, K. (2000), "Cognitive biases, risk perception, and venture formation: how individuals decide to start companies", Journal of Business Venturing, Vol. 15 No. 2, pp. 113-134.

Sloof, R. and von Siemens, F.A. (2017), "Illusion of control and the pursuit of authority", Experimental Economics, Vol. 20 No. 3, pp. 556-573.

Statistik Hessen (2011), “Größenstruktur der landwirtschaftlichen Betriebe in Hessen 2010”, available at: https://www.statistischebibliothek.de/mir/servlets/MCRFileNodeServlet/HEHeft_derivate_ 00000170/CIV7_6j10.pdf.

Stephens, A.N. and Ohtsuka, K. (2014), "Cognitive biases in aggressive drivers: does illusion of control drive us off the road?", Personality and Individual Differences, Vol. 68, pp. 124-129.

Taleb, N.N. (2005), Fooled by Randomness: the Hidden Role of Chance in Life and in the Markets (Incerto 1), Random House, New York City.

Thaler, R.H. (2012), The Winner's Curse: Paradoxes and Anomalies of Economic Life, Simon \& Schuster, New York City.

Thompson, S.C. (1999), "Illusions of control: how we overestimate our personal influence", Current Directions in Psychological Science, Vol. 8 No. 6, pp. 187-190.

Viceisza, A.C.G. (2016), "Creating a lab in the field: economics experiments for policymaking”, Journal of Economic Surveys, Vol. 30 No. 5, pp. 835-854.

Vollmer, E., Hermann, D. and Musshoff, O. (2017), "An experimental approach to the investment timing of conventional and organic hog farmers", Canadian Journal of Agricultural Economics/ Revue Canadienne D’agroeconomie, Vol. 65 No. 2, pp. 293-315. 
Weigel, C., Paul, L.A., Ferraro, P.J. and Messer, K.D. (2021), "Challenges in recruiting US farmers for policy-relevant economic field experiments", Applied Economic Perspectives and Policy, Vol. 43 No. 2, pp. 556-572.

White, R.W. (1959), "Motivation reconsidered: the concept of competence", Psychological Review, Vol. 66 No. 5, pp. 297-333.

Wood, W.S. and Clapham, M.M. (2005), "Development of the Drake beliefs about chance inventory", Journal of Gambling Studies, Vol. 21 No. 4, pp. 411-430.

Yarritu, I., Matute, H. and Vadillo, M.A. (2014), "Illusion of control: the role of personal involvement", Experimental Psychology, Vol. 61 No. 1, pp. 38-47.

Zizzo, D.J. (2010), "Experimenter demand effects in economic experiments", Experimental Economics, Vol. 13 No. 1, pp. 75-98.

\section{Appendix}

\begin{tabular}{|c|c|c|c|c|}
\hline & $\begin{array}{c}\text { (1) } \\
\text { (Full sample with } \\
\text { interaction effect) }\end{array}$ & $\begin{array}{c}(2) \\
\text { (Only if Risk } \\
\text { attitude smaller } \\
\text { than } 7)\end{array}$ & $\begin{array}{c}\text { (3) } \\
\text { (Only if Risk attitude } \\
\text { smaller than 7) }\end{array}$ & $\begin{array}{c}(4) \\
\text { (Only if Risk } \\
\text { attitude smaller } \\
\text { than } 7)\end{array}$ \\
\hline Treatment & $-3940.1(7521.4)$ & $6785.3(5761.9)$ & 7376.7 (5649.5) & 10173.0 (7121.2) \\
\hline Friday & $-6568.3(5120.1)$ & $-7831.0(5,731.0)$ & $-6341.4(5777.8)$ & $-5983.7(7216.5)$ \\
\hline Dohmen interact & 1582.8 (923.7) & & & \\
\hline $\begin{array}{l}\text { (Treatment } \times \text { Risk } \\
\text { attitude) }\end{array}$ & & & & \\
\hline Gender & & & $-22686.9(13236.4)$ & \\
\hline Age & & & -352.5 (206.5) & $-347.5(276.1)$ \\
\hline Risk attitude & & & 3181.3 (2225.6) & 2935.0 (2861.9) \\
\hline Main income & & & & 8224.5 (11426.8) \\
\hline Livestock units & & & & $-38.98(92.97)$ \\
\hline Arable land & & & & -19.57 (99.87) \\
\hline Econ courses & & & & 4878.6 (7804.2) \\
\hline Constant & $53848.9^{* * * * *}(8512.6)$ & $49383.3^{* * * *}(9276.8)$ & $50613.0^{* * * * *}(14273.9)$ & $42589.9^{*}$ (19525.1) \\
\hline Observations & 88 & 58 & 58 & 49 \\
\hline$F$ & 1.822 & 1.627 & 1.869 & 0.843 \\
\hline$r 2 \_a$ & 0.0275 & 0.0215 & 0.0708 & -0.0269 \\
\hline
\end{tabular}

Note(s): Standard errors in parentheses

${ }^{*} p<0.05,{ }^{* * *} p<0.01,{ }^{* * * *} p<0.001$

Column (1) presents regression coefficient estimates with an interaction effect of the treatment dummy and the risk attitude to test whether the treatment effect is mediated by risk. The coefficient is rather small and statistically not significant

Columns (2) to (4) re-estimate the models presented in Table 4 of the main text for the sub-sample of risk-averse participants (with risk attitude $<7$ ). This results in a smaller sample (30 participants are removed in (2) and (3); due to missing observations for covariates in (4), 9 additional participants drop out). Note that the gender coefficient cannot be estimated for (4), as there are no women in the sub-sample

Table A1.

Additional regressions adjusting for socioeconomic heterogeneity (dependent variable is the amount allocated to the risky option)

\section{Corresponding author}

Jens Rommel can be contacted at: jens.rommel@slu.se

For instructions on how to order reprints of this article, please visit our website:

www.emeraldgrouppublishing.com/licensing/reprints.htm

Or contact us for further details: permissions@emeraldinsight.com 